\title{
Dependency of Evaporation and Class A Pan Coefficient on Meteorological Parameters
}

\author{
Antensay Mekoya* \\ Ethiopia Environment and Forest Research Institute, Bahir Dar Environment and Forest Research Center, Ethiopia
}

Submission: March 16, 2020; Published: April 14, 2020

*Corresponding author: Antensay Mekoya, Ethiopia Environment and Forest Research Institute, Bahir Dar Environment and Forest Research Center, P.O. Box: 2128 Bahir Dar, Ethiopia

\section{Abstract}

The relation of evaporation deriving meteorological parameters particularly wind speed, solar radiation and vapor pressure deficit with evaporation schemes namely Class A pan evaporation (Ep), potential evapotranspiration (PET) and reference evapotranspiration (ETo) at Tharandt, Germany for the summer half-year of 2004-2013 was investigated. PET was calculated using three methods: 1. Haude (2005), 2. Wendling (1991), 3. Penman (1963); whereas, ET was calculated according to Food and Agricultural Organization-Penman Monteith method. The results showed that the evaporatin schemes were mainly driven by solar radiation $\left(R^{2} \geq 0.69\right.$, RMSE $\left.\leq 0.76 \mathrm{~mm} \mathrm{~d}^{-1}\right)$ and vapor pressure deficit $\left(R^{2} \geq 0.53\right.$, RMSE $\left.\leq 0.92 \mathrm{~mm} \mathrm{~d}^{-1}\right)$. The effect of wind speed at $2 \mathrm{~m}$ in deriving the evaporation schemes was negligibly small $\left(\mathrm{R}^{2}<0.12\right)$. An equation is derived for estimation of $\mathrm{E}_{\mathrm{p}}$ from measured meteorological parameters alone which makes this study special. In another scenario, Class $\mathrm{A}$ pan coefficient $\left(K_{p}\right)$ which is the ratio of $E_{0}$ and $E_{p}$ had shown good correlation with $E_{p}$ only $\left(R^{2}=0.50, R M S E=0.19, n=1483\right)$. The correlation of $\mathrm{K}_{\mathrm{p}}$ with $\mathrm{ET}_{\mathrm{o}^{\prime}}$, shortwave radiation, wind speed at $2 \mathrm{~m}$, vapor pressure deficit, relative air humidity, and air temperature was too low $\left(\mathrm{R}^{2}<0.1\right)$.

Keywords: Class A pan evaporation; Class A pan coefficient; Solar radiation; Vapor pressure deficit; Air temperature; Relative air humidity; Wind speed; Reference evapotranspiration; Potential evapotranspiration; Summer half-year; Tharandt

Abbreviations: E : Class A Pan evaporation; K: Class A Pan Coefficient; PET: potential evapotranspiration; ET : reference evapotranspiration; SHY: summer half-year which is the time from april to september; PETs: PET estimated according to Haude, Wendling, and Penman; $R_{n}$ : net solar radiation; $\mathrm{R}_{\mathrm{s}}$ : solar or shortwave or incoming radiation; $\mathrm{u}_{2}$ : wind speed at $2 \mathrm{~m}$; VPD: vapor pressure deficit; $\mathrm{RH}$ : relative air humidity; T: air temperature; Haude7: PET calculated according to Haude in which 17 values which were greater than $7 \mathrm{~mm} \mathrm{~d}^{-1}$ are replaced by $7 \mathrm{~mm} \mathrm{~d}^{-1}$

\section{Introduction}

Evaporation does not take place at a constant rate as its rate naturally depends on meteorological, geographical, and topographical factors. The principal meteorological parameters affecting evapotranspiration are solar radiation, air temperature, relative air humidity and wind speed (Trajković and Živković (2009) as cited in Isikwue BC et al. [1] p.698; also refer Moderow et al. [2] and Wang \& Dickinson [3]. Vapor pressure deficit (i.e., air humidity and air temperature) is also one of the meteorological parameters which affect evaporation or evapotranspiration [4]. The rate at which molecules leave water depends on the vapor pressure of the water $\left(\mathrm{e}_{\mathrm{w}}\right)$ and the rate at which molecules enter the air depends on the vapor pressure of the air $\left(\mathrm{e}_{\mathrm{a}}\right)$ above the water surface. Thus, the rate of evaporation depends on the difference between them called vapor pressure deficit (VPD); i.e., $\mathrm{VPD}=\mathrm{e}_{\mathrm{w}}-\mathrm{e}_{\mathrm{a}}$. Therefore, evaporation is proportional to $\left(\mathrm{e}_{\mathrm{w}}-\mathrm{e}_{\mathrm{a}}\right)$ and continuous until $\mathrm{e}_{\mathrm{w}}=\mathrm{e}_{\mathrm{a}}$. Similarly, evaporation is proportional to the difference between actual humidity and the saturated humidity at a given temperature.
In this article, the dependency of the methods of estimation of PET estimated according to Haude (Haude7), Wendling and Penman and ET estimated according to FA056-PM method on wind speed at $2 \mathrm{~m}\left(\mathrm{u}_{2}\right), \mathrm{VPD}$, and shortwave and net solar radiation $\left(R_{s} \& R_{n}\right)$ at Tharandt from 2004 to 2013 for the summer half-year $(\mathrm{n}=1830)$ was investigated. The summer half-year dependency of Class A pan evaporation $\left(\mathrm{E}_{\mathrm{p}}\right)$ with $\mathrm{u}_{2}, \mathrm{VPD}$, and $\mathrm{R}_{\mathrm{s}} \& \mathrm{R}_{\mathrm{n}}$ as well as with air temperature and with relative air humidity was also investigated $(\mathrm{n}=1709)$.

\section{Data and Methodology}

The study area was Tharandt, Germany (altitude: $220 \mathrm{~m}$ a.s.l, latitude: $50^{\circ} 58^{\prime} 42.06^{\prime \prime} \mathrm{N}$, longitude: $\left.13^{\circ} 34^{\prime} 52.69^{\prime \prime} \mathrm{E}\right)$. Ten years (01.01.2004 to 31.12.2013) daily and ten minutes data of Tharandt meteorological station was the basis of the data set. The meteorological parameters and measurement devices used for the study are presented in Table 1. 


\section{International Journal of Environmental Sciences \& Natural Resources}

Table 1: Primary and Secondary Meteorological data used for the study

\begin{tabular}{|c|c|c|}
\hline Parameter & Notation & Measurement Device \\
\hline relative humidity in $\%$ at 2 p.m. & $\mathrm{RH}_{2 \mathrm{pm}, \mathrm{P}}$ & Psychrometer \\
\hline air temperature in ${ }^{\circ} \mathrm{C}$ at 2 p.m. & $\mathrm{T}_{2 \mathrm{pm}}$ & Humidity Moisture Probe HMP45 \\
\hline relative humidity in $\%$ at 2 p.m. & $\mathrm{RH}_{2 \mathrm{pm}}$ & HMP45 \\
\hline air temperature in ${ }^{\circ} \mathrm{C}$ at 2 p.m. & $\mathrm{T}_{2 \mathrm{pm}, \mathrm{rt}}$ & resistance thermometer (Pt100) \\
\hline wind speed in $\mathrm{m} \mathrm{s}^{-1}$ at $3 \mathrm{~m}$ above ground & $\mathrm{u}_{3}$ & Young Anemometer \\
\hline Wind speed in $\mathrm{m} \mathrm{s}^{-1}$ at $10 \mathrm{~m}$ above ground & $\mathrm{u}_{10}$ & Young Anemometer \\
\hline Precipitation per day in $\mathrm{mm}$ (measured at 7 a.m.) & $\mathrm{P}$ & $\begin{array}{l}\text { Hellmann mit Windring (verzinkt/ } \\
\text { V2A) }\end{array}$ \\
\hline $\begin{array}{l}\text { Precipitation per day in mm (automatic measurement at midnight): recorded } \\
\text { every } 10 \text { minutes. A value of } 144 \text { indicates that for every interval of } 10 \text { min length } \\
\text { a proper value was obtained. Values less than } 144 \text { indicate that the measurement } \\
\text { device did not function in every time interval }\end{array}$ & $\mathrm{RF}$ & Precipitation gauge (Pluvio) \\
\hline Global radiation measured at the roof of the Stöckhardtbau in $\mathrm{W} \mathrm{m}{ }^{-2}$ & $\mathrm{R}_{\mathrm{s}, \text { roof }}$ & Pyranometer (CM7) \\
\hline Global radiation in $\mathrm{W} \mathrm{m}^{-2}$ at $3 \mathrm{~m}$ above ground & $\mathrm{R}_{\mathrm{s}}$ & Pyranometer (SP Lite) \\
\hline 10 minutes values Water table height in $\mathrm{mm}$ & $V^{\prime}$ & $\begin{array}{c}\text { Class-A pan (derived from pressure } \\
\text { changes) }\end{array}$ \\
\hline Maximum air temperature in ${ }^{\circ} \mathrm{C}$ & $\mathrm{T}_{\max }$ & Thermometer \\
\hline Minimum air temperature in ${ }^{\circ} \mathrm{C}$ & $\mathrm{T}_{\min }$ & Thermometer \\
\hline Maximum relative air humidity in $\%$ at $2 \mathrm{~m}$ above ground & $\mathrm{RH}_{\max }$ & HMP45 \\
\hline Minimum relative air humidity in $\%$ at $2 \mathrm{~m}$ above ground & $\mathrm{RH}_{\min }$ & HMP45 \\
\hline Daily values (7 a.m. to 7 a.m. of the next day) Water level height in $\mathrm{mm}$ & $\mathrm{V}$ & $\begin{array}{c}\text { Class-A pan (derived from pressure } \\
\text { changes) }\end{array}$ \\
\hline
\end{tabular}

(Source: Dr. Uta Moderow; TU Dresden, IHM, Chair of Meteorology).

The pan used for measurement of pan evaporation is the World Meteorological Organization (WMO) standard Class A pan evaporimeter (see Figure 1). Class A pan evaporation ( $E_{p}$ ) is calculated as described in Mekoya et al. [6]. PET estimated using three methods:

b) Wendling (1991) as cited in Wendling [8]; and

c) Penman (1963) as cited in ASCE-EWRI [9].

$\mathrm{ET}_{\mathrm{o}}$ is estimated according to Allen et al. [10] (FA056-PM). Net radiation $\left(R_{n}\right)\left(\right.$ in $\left.M^{-2} m^{-2} d^{-1}\right)$ is also calculated as described in Allen et al. [10].

a) Haude (2005) as cited in Weiß [7];

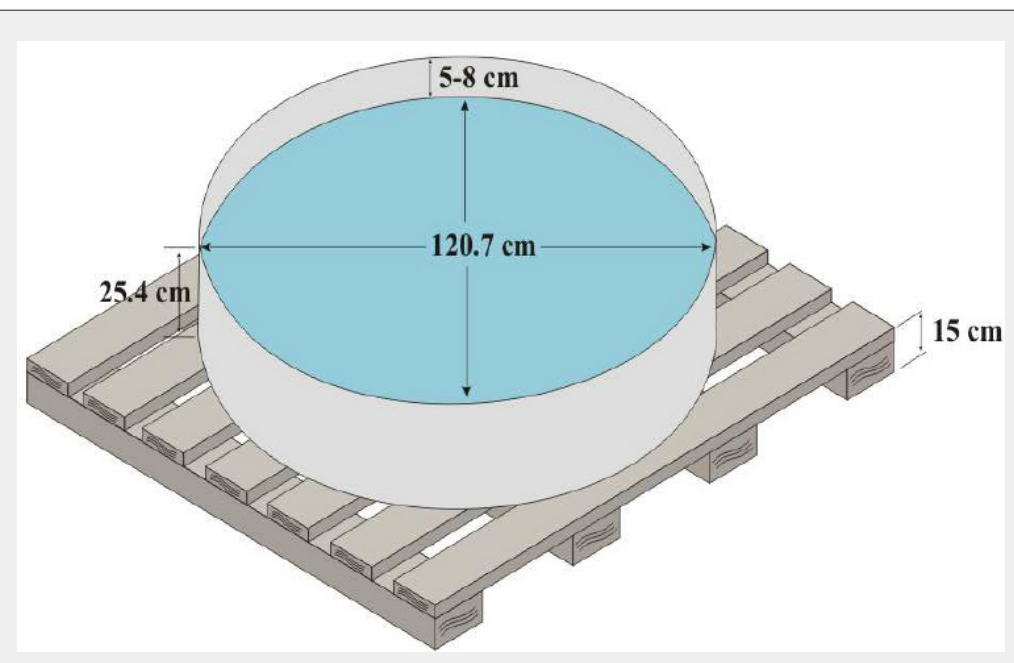

Figure 1: Appearance of Class A pan and its dimensions (source: Ertek [5], p.6708). 
For the analyses, measured shortwave radiation in $\mathrm{MJ} \mathrm{m}^{-2}$ $\mathrm{d}^{-1}$ at $3 \mathrm{~m}$ above ground $\left(\mathrm{R}_{\mathrm{s}}\right)$ was used. At Tharandt over the ten years (2004 to 2013) the average, extreme maximum and extreme minimum values of net radiation $\left(\mathrm{R}_{\mathrm{n}}\right)$ were $8.87,26.83$ and $0.10 \mathrm{MJ}$ $\mathrm{m}^{-2} \mathrm{~d}^{-1}$; whereas its corresponding values of $R_{\mathrm{s}}$ were $6.19,15.87$ and $-0.96 \mathrm{MJ} \mathrm{m}^{-2} \mathrm{~d}^{-1}$, respectively. below.

Saturation vapor pressure $\left(\mathrm{e}_{\mathrm{s}}\right)$ in $\mathrm{kPa}$ is calculated as given

$$
e_{s}(T)=0.6108 . \exp \left[\frac{17.27}{(T+237.3)}\right] ; \quad[1]
$$

Where, $\mathrm{T}$ is air temperature $\left(\mathrm{in}^{\circ} \mathrm{C}\right)$.

To get saturation vapor pressure $\left(\mathrm{e}_{\mathrm{s}}\right)$ in $\mathrm{hPa}$ using $\mathrm{T}_{2 \mathrm{pm}}$, Eq. 1 is modified as

$$
e_{s}\left(T_{2 p m}\right)=0.6108 \cdot \exp \left[\frac{17.27 * T_{2 p m}}{\left(T_{2 p m}+237.3\right)}\right]
$$

Relative humidity in \% (RH) expresses the degree of saturation of the air as a ratio of the actual $\left(e_{a}\right)$ to the saturation $\left(e_{s}\right)$ vapor pressure at the same temperature.

$$
R H=100 \cdot \frac{e_{a}}{e_{s}} ;[1]
$$

Modifying Eq. 2 and replacing $\mathrm{RH}$ with $\mathrm{RH}_{2 \mathrm{pm}}$, we have:

$$
e_{a}=100 \cdot \frac{R H_{2 p m}}{e_{s}}
$$

Generally, daily vapor pressure deficit (VPD) in $\mathrm{kPa}$ was calculated using Eq. 1 and Eq. 2. However, in the case of PET according to Haude, VPD in hPa was calculated using Eq. 1a and Eq. 3. Daily wind speed at $2 \mathrm{~m}$ above ground $\left(\mathrm{u}_{2}\right)$ in $\mathrm{m} \mathrm{s}^{-1}$ is calculated as given below.

$$
u_{2}=u_{z} \frac{4.87}{\ln (67.8 z-5.42)} ;[1]
$$

$$
u_{2}=\frac{u_{z} * 4.2}{(3.5+\ln (z))} ;[8]
$$

Where $\mathrm{u}_{\mathrm{z}}$ is measured wind speed at $\mathrm{z} \mathrm{m}$ above the ground surface (in $\mathrm{m} \mathrm{s}^{-1}$ ), and $\mathrm{z}$ is height of measurement above the ground surface (in $\mathrm{m}$ ).

Daily wind speed at $2 \mathrm{~m}$ above ground $\left(\mathrm{u}_{2}\right)$ in $\mathrm{m} \mathrm{s}^{-1}$ is used as calculated in Eq. 4 (except for PET according to Wendling which uses Eq. 5).

Finally, the degree of dependency of evaporation schemes on $\mathrm{u}_{2}, \mathrm{VPD}, \mathrm{R}_{\mathrm{s}}$ and $\mathrm{R}_{\mathrm{n}}$ was evaluated using a linear regression model where values of Pearson's correlation coefficient (r), R², RMSE, and p-value (at 95\% confidence interval or at 0.05 significant level) were used for assessing the fit of the regression model.

\section{Results and Discussions}

\section{Evaporation schemes and meteorological parameters}

\section{The dependency of evaporation schemes on wind speed}

Figure 2 shows the dependency of potential evaporation schemes namely PET according to Haude, Haude7, Wendling and Penman with wind speed at $2 \mathrm{~m}$. Similarly, Figure 3 shows the dependency of reference evapotranspiration and Class A pan evaporation with $\mathrm{u}_{2}$. Generally PET schemes, $\mathrm{ET}_{\mathrm{o}}$, and $\mathrm{E}_{\mathrm{p}}$ had shown significantly poor dependency with $\mathrm{u}_{2}$. The dependency was nonsignificant ( $p$-value $>0.05$ ) only in the case of PET estimated according to Haude7. Moreover, PETs, $\mathrm{ET}_{\mathrm{o}}$ and $\mathrm{E}_{\mathrm{p}}$ increased with increasing wind speed at $2 \mathrm{~m}$ for $\mathrm{u}_{2} \leq 1 \mathrm{~m} \mathrm{~s}^{-1}$ and slightly decreased with increasing values of $\mathrm{u}_{2}$ for $\mathrm{u}_{2}>1 \mathrm{~m} \mathrm{~s}^{-1}$, where in all cases $\mathrm{R}^{2}$ was less than 0.1 (not shown).
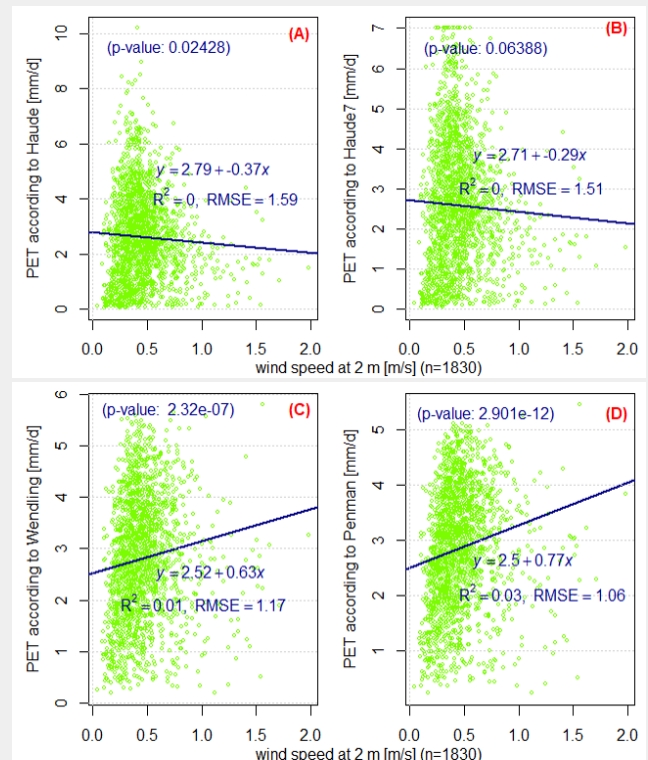

Figure 2: Dependency of PET estimated according to Haude (figure 'A'), 'Haude7' (figure 'B'), Wendling (figure 'C'), and Penman (figure 'D') on wind speed at $2 \mathrm{~m}$. 


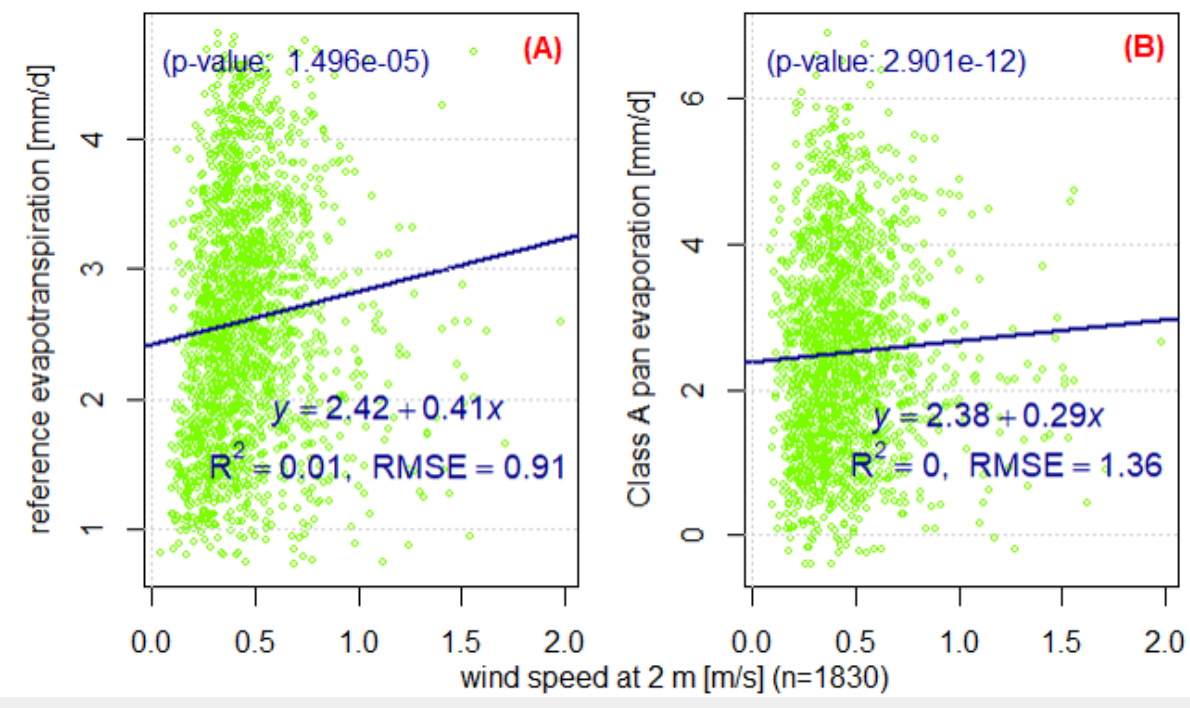

Figure 3: Dependency of reference evapotranspiration (figure 'A') and Class A pan evaporation (figure 'B') on wind speed at $2 \mathrm{~m}$

The dependency of evaporation schemes on vapor

\section{pressure deficit}

The dependency of PETs and $\mathrm{ET}_{\mathrm{o}}$ with vapor pressure deficit was high $\left(\mathrm{R}^{2} \geq 0.78 ; \mathrm{RMSE} \leq 0.62 \mathrm{~mm} \mathrm{~d}^{-1}\right)$ and significant ( $\mathrm{p}$-value $<$ $\left.2.2 \cdot 10^{-16}<0.05\right)$; the dependency in the case of $\mathrm{E}_{\mathrm{p}}$ was also 'slightly strong' $\left(\mathrm{R}^{2}=0.53\right.$; RMSE $\left.=0.93 \mathrm{~mm} \mathrm{~d}^{-1}\right)$ and significant (see Figure 4 \& 5). Particulary in the case of PET according to Haude it was extremely high $\left(\mathrm{R}^{2}=0.98\right.$; RMSE $\left.=0.23 \mathrm{~mm} \mathrm{~d}^{-1}\right)$ and significant. Note that PET according to Haude is calculated by multiplying calibrated factor and VPD.
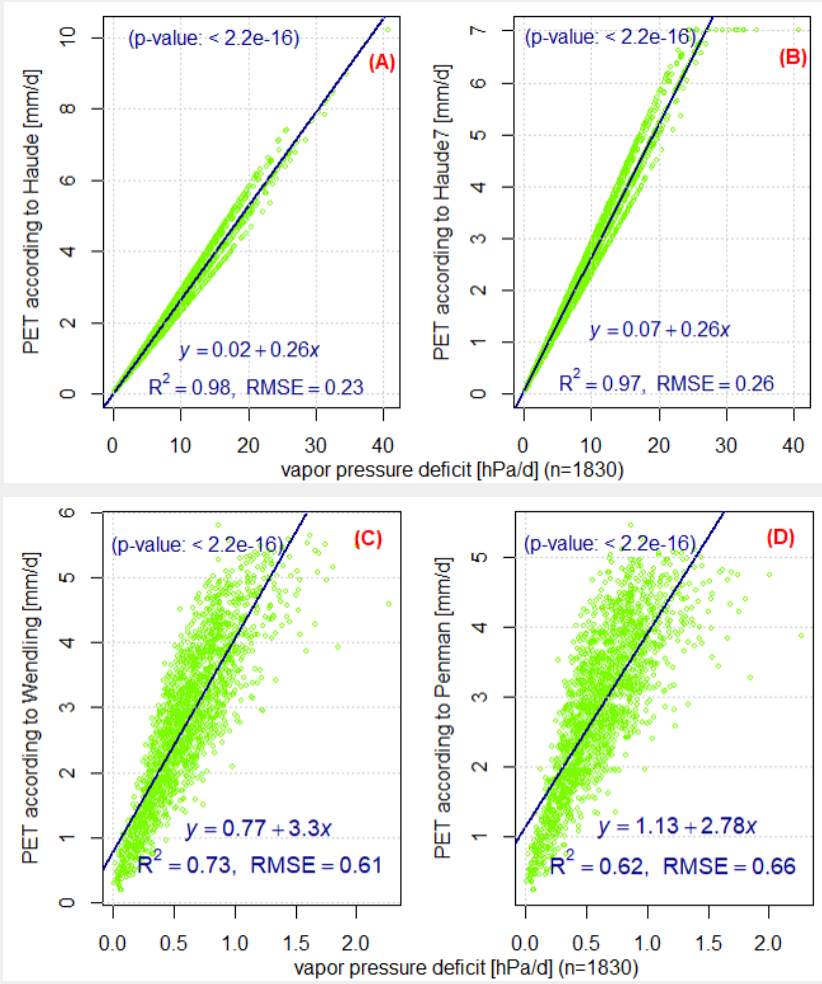

Figure 4: Dependency of PET estimated according to Haude (figure 'A'), 'Haude7' (figure 'B'), Wendling (figure 'C'), and Penman (figure 'D') on vapor pressure deficit. 

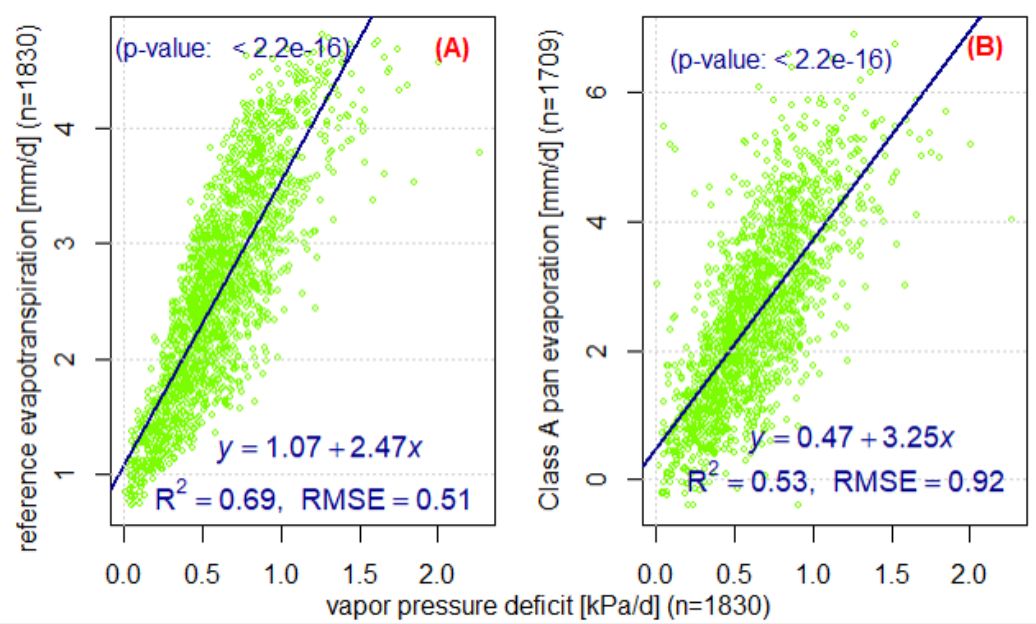

Figure 5: Dependency of reference evapotranspiration (figure 'A') and Class A pan evaporation (figure 'B') on vapor pressure deficit.

The dependency of evaporation schemes on solar

\section{radiation}

Figure 6 \& 7 show that the dependency of PETs and ET on shortwave or solar radiation was high $\left(R^{2} \geq 0.89\right)$. The dependency of $E_{p}$ on $R_{s}$ was also a bit high $\left(R^{2}=0.69\right.$; $\left.R M S E=0.76 \mathrm{~mm} \mathrm{~d}^{-1}\right)$.
The dependency was extremely high in the case of Penman and Wendling PETs $\left(\mathrm{R}^{2} \geq 0.98\right)$. The dependency of evaporation schemes on net solar radiation was very high and significant particularly in the case of ET ${ }_{0}$, and PET according to Wendling and Penman (see Table 2).

Table 2: Dependency of evaporation schemes on net solar radiation.

\begin{tabular}{|c|c|c|c|c|}
\hline $\mathbf{y}=\mathbf{a x}+\mathbf{b}$ & $\mathbf{E T}_{\mathbf{o}}$ & Penman PET & Wendling PET & Haude PET \\
\hline $\mathbf{R}^{\mathbf{2}}$ & 0.94 & 0.91 & 0.92 & 0.55 \\
\hline $\mathbf{R M S E}$ & 0.23 & 0.32 & 0.33 & 1.07 \\
\hline $\mathbf{a}$ & 0.31 & 0.4 & 0.41 & 0.42 \\
\hline $\mathbf{b}$ & -0.38 & -0.97 & -1.39 & -1.35 \\
\hline
\end{tabular}

\section{Further on evaporation schemes and meteorological parameters}
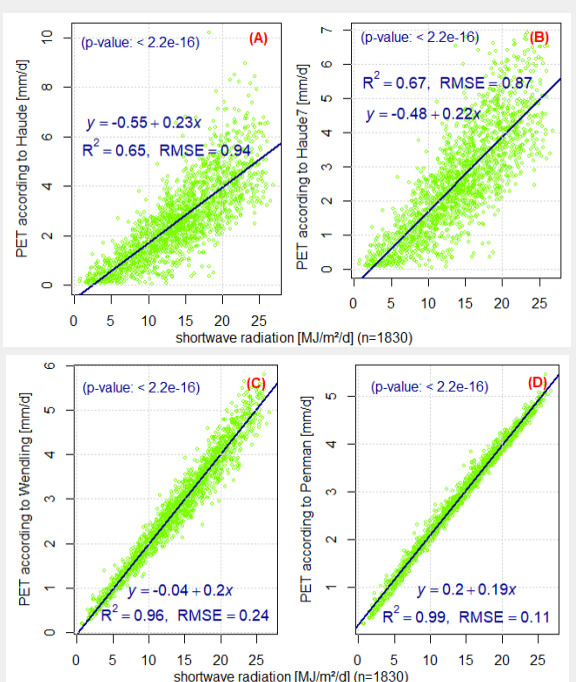

Figure 6: Dependency of PET estimated according to Haude (figure 'A'), 'Haude7' (figure 'B'), Wendling (figure 'C'), and Penman (figure 'D') on shortwave radiation 

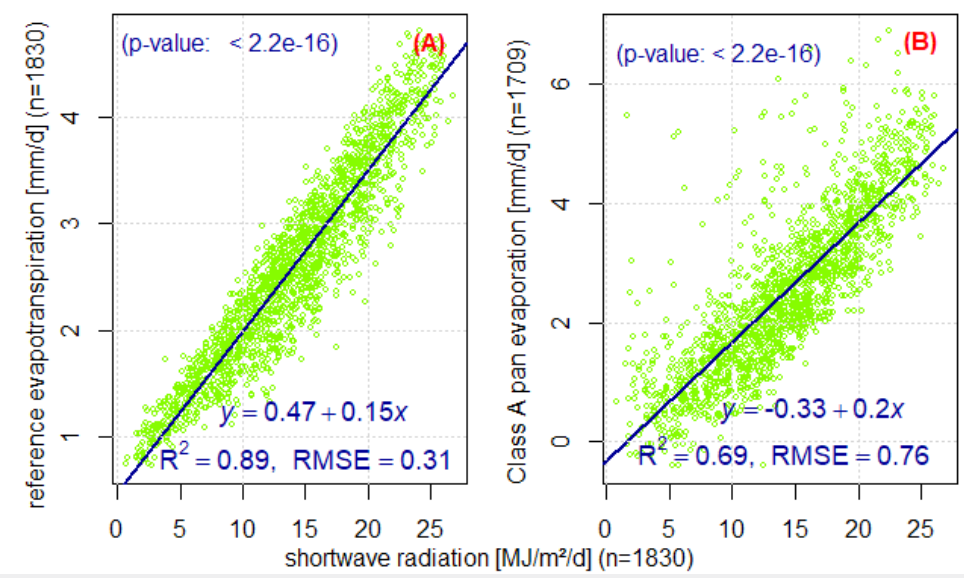

Figure 7: Dependency of reference evapotranspiration (figure 'A') and Class A pan evaporation (figure 'B') on shortwave radiation.

The relation between the evaporation schemes with maximum air temperature are presented in Figure 8 \& 9. Generally, the correlation of the evaporation schemes with air temperature (not shown) was lower as compared to their correlation with maximum air temperature. A significant positive correlation $(r \geq$ $0.6)$ was observed between all evaporation schemes and maximum air temperature. Also, the relation of air humidity with the evaporation schemes is presented in Table 3, the corresponding graph for $\mathrm{ET}_{\mathrm{o}}$ and $\mathrm{E}_{\mathrm{p}}$ is presented in Figure 10. For minimum relative air humidity and relative air humidity a significant good negative correlation $(\mathrm{r} \leq-0.7)$ was observed with all evaporation schemes except $\mathrm{E}_{\mathrm{p}}$ (see Table 3 \& 4). The intercorrelation between $\mathrm{ET}_{\mathrm{o}}$, PET according to Wendling, and PET according to Penman was very high $(r>0.9)$.
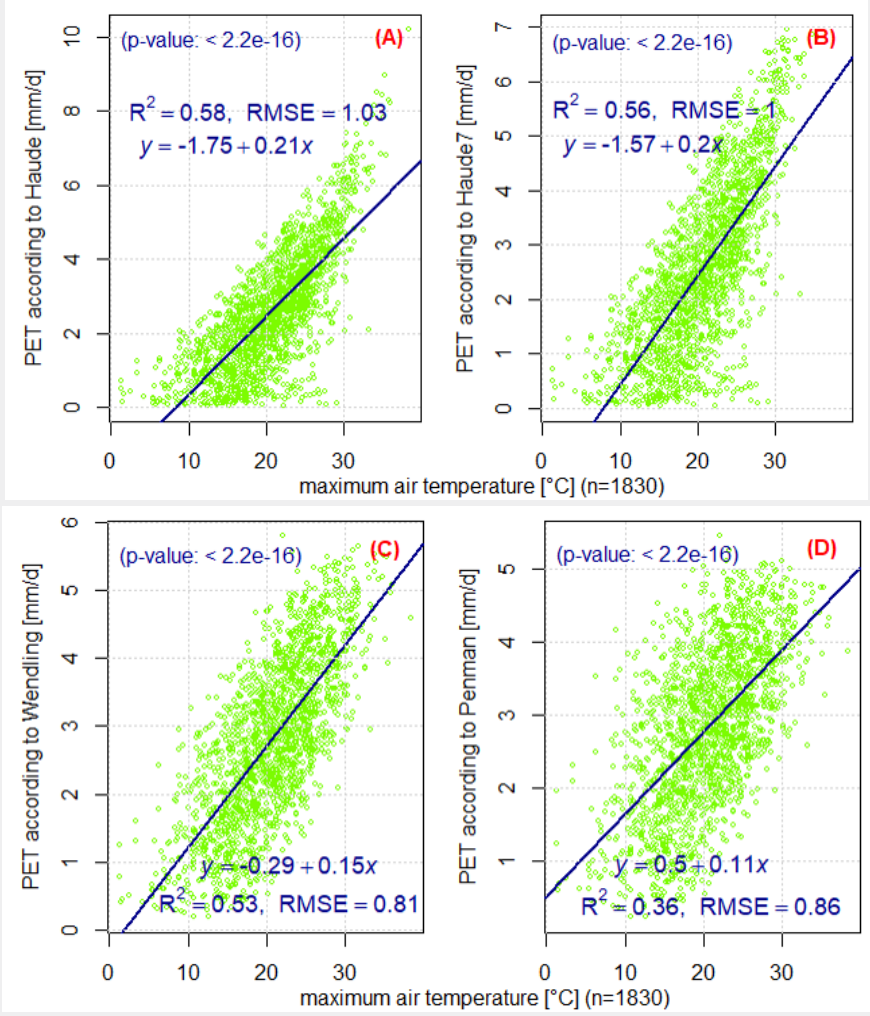

Figure 8: Relation between PET estimated according to Haude (figure 'A'), 'Haude7' (figure 'B'), Wendling (figure 'C'), and Penman (figure 'D') with maximum air temperature. 
Table 3: Correlation between evaporation schemes with air humidity and with each other.

\begin{tabular}{|c|c|c|c|c|}
\hline Correlation (r) & ET $_{\mathbf{o}}$ & Penman PET & Wendling PET & Haude PET \\
\hline $\mathbf{R H}_{\max }$ & -0.21 & -0.29 & -0.25 & -0.26 \\
\hline $\mathbf{R H}$ & -0.67 & -0.82 & -0.77 & -0.79 \\
\hline $\mathbf{R H}_{\text {min }}$ & -0.69 & -0.84 & -0.79 & 0.81 \\
\hline ET $_{\mathbf{o}}$ & 1 & 0.93 & 0.98 & 0.82 \\
\hline Penman PET & 0.93 & 1 & 0.98 & 0.86 \\
\hline Wendling PET & 0.98 & 0.98 & 1 & 1 \\
\hline Haude PET & 0.82 & 0.82 & 0.86 & \\
\hline
\end{tabular}

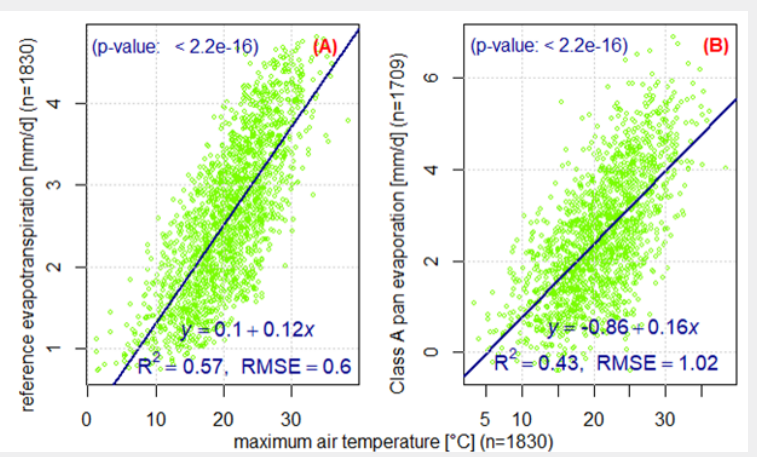

Figure 9: Relation between reference evapotranspiration (figure 'A') and Class A pan evaporation (figure 'B') with maxium air temperature
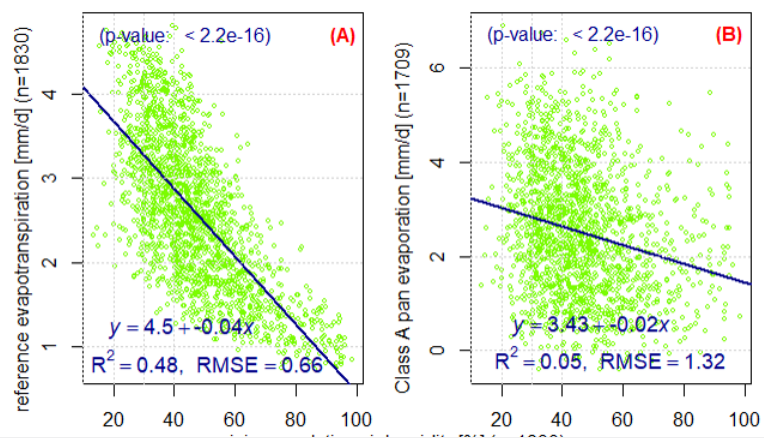

Figure 10: Relation between reference evapotranspiration (figure ' $A$ ') and Class $A$ pan evaporation (figure 'B') with minimum relative air humidity.
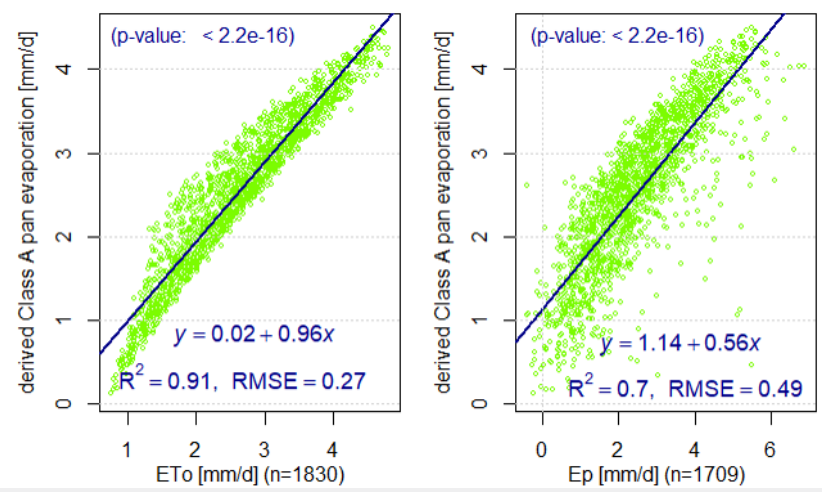

Figure 11: Relation between derived Class A pan evaporation with reference evapotranspiration and Class A pan evaporation. 


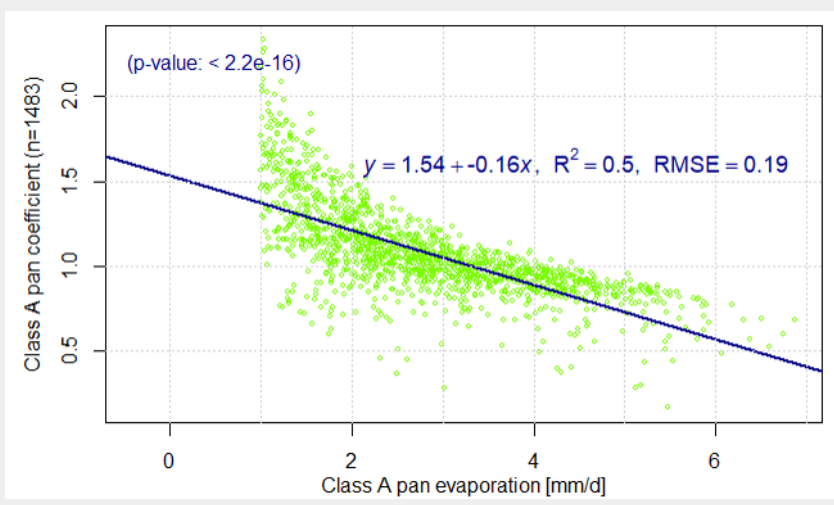

Figure 12: Dependency of Class A pan coefficient on Class A pan evaporation.

Table 4: Dependency of Class A pan evaporation on meteorological parameters.

\begin{tabular}{|c|c|c|c|c|c|c|c|c|c|}
\hline$y=a x+b$ & $\mathrm{ET}_{\mathrm{o}}$ & $\mathbf{R}_{\mathbf{n}}$ & $\mathbf{R}_{\mathrm{s}}$ & $K_{p}$ & VPD & $\mathbf{T}_{\max }$ & $\mathbf{R H}_{\text {min }}$ & RH & $\mathbf{T}$ \\
\hline $\mathbf{r}$ & 0.88 & 0.84 & 0.83 & 0.71 & 0.73 & 0.66 & 0.6 & 0.59 & 0.58 \\
\hline $\mathbf{R}^{2}$ & 0.78 & 0.71 & 0.69 & 0.5 & 0.53 & 0.43 & 0.36 & 0.35 & 0.34 \\
\hline RMSE & 0.63 & 0.73 & 0.76 & 0.84 & 0.92 & 1.02 & 1.08 & 1.09 & 1.1 \\
\hline a & 1.33 & 0.41 & 0.2 & -3.09 & 3.25 & 0.16 & -0.05 & -0.09 & 0.18 \\
\hline b & -0.99 & -1.39 & -0.33 & 6.16 & 0.49 & -0.86 & 5.01 & 9.16 & -0.17 \\
\hline $2\left(\mathrm{R}^{2}+1-\mathrm{RMSE}\right)$ & 2.3 & 1.96 & 1.86 & 1.32 & 1.22 & 0.82 & 0.56 & 0.52 & 0.48 \\
\hline
\end{tabular}

Derivation of equations for estimation of Class A pan evaporation

The Pearson's correlation coefficient $(r), R^{2}, R M S E$, the slope (a), the y-intercept (b), and an accuracy factor ' $F$ ' $=2\left(R^{2}+1\right.$ - RMSE) of the linear regression model ( $y=a x+b$ ') described before are summarized in Table 4 . F ranges from negative values to 4 . Negative values of $\mathrm{F}$ indicate no accuracy and $\mathrm{F}=4$ indicates perfect alignment of model prediction or simulated or estimated data (y) and simulator or measured data (x). $\mathrm{E}_{\mathrm{p}}$ can be estimated with good accuracy from $\mathrm{ET}_{\mathrm{o}}, \mathrm{R}_{\mathrm{n}}, \mathrm{K}_{\mathrm{p}}$, and VPD as given below, where $y$ is replaced by $E_{p}$ and $x$ is replaced by $E_{o^{\prime}}, R_{n^{\prime}} K_{p^{\prime}}, V P D, R_{s^{\prime}}$ $\mathrm{T}_{\text {max }}, \mathrm{RH}_{\text {min }}, \mathrm{RH}$ and $\mathrm{T}$.

$$
\begin{aligned}
& E_{p_{-} E T_{o}}=1.33 E T_{o}-0.99 \\
& E_{p_{-} R n}=0.41 R_{n}-1.39 \\
& E_{p_{-} K p}=0.49-3.09 K_{p} \\
& E_{p_{-} V P D}=3.25 \mathrm{VPD}+0.47
\end{aligned}
$$

However, the calculation of $\mathrm{ET}_{\mathrm{o}}, \mathrm{R}_{\mathrm{n}}, \mathrm{K}_{\mathrm{p}}$ and VPD is not a simple task as it requires many parameters to be fulfilled. In contrast, estimation of $\mathrm{E}_{\mathrm{p}}$ using only measured meteorological parameters such as $\mathrm{R}_{\mathrm{s}^{\prime}} \mathrm{T}_{\text {max }}, \mathrm{RH}_{\text {min }}, \mathrm{RH}$, and $\mathrm{T}$ which can be easily obtained from meteorological offices on request has been desired and are given below.

$$
\begin{aligned}
& E_{p_{-} R s}=0.2 R_{s}-0.33 \\
& E_{p_{-} T \max }=0.16 T_{\max }-0.86 \\
& E_{p_{-} R H \min }=5.01-0.05 R H_{\text {min }} \\
& E_{p_{-} R H}=9.16-0.09 R_{s} \\
& E_{p_{-} T}=0.18 T-0.17
\end{aligned}
$$

Comparatively relative air humidity $(\mathrm{RH})$ and air temperature (T) have lower values of accuracy factor (F). Therefore, using weighted average of F and Eq. 10, Eq. 11 and Eq. 12, Class A pan evaporation $\left(E_{p}\right)$ in $\mathrm{mm} \mathrm{d}^{-1}$ can be estimated with good accuracy from Rs, $\mathrm{T}_{\text {max }}$ and $\mathrm{RH}_{\min }$ as $\left[1.86(0.2 \mathrm{Rs}-0.33)+0.82\left(0.16 \mathrm{~T}_{\max }\right.\right.$ $\left.0.86)+0.56\left(5.01-0.05 \mathrm{RH}_{\text {min }}\right)\right] /(1.86+0.82+0.56) \approx(0.4 \mathrm{Rs}+$ $0.13 \mathrm{~T}_{\max }-0.03 \mathrm{RH}_{\min }+1.5$ )/3.24 (see Eq. 15)

$E_{p d}=\left(0.372 R_{s}+0.1312 T_{\max }-0.028 R H_{\min }+1.4866\right) / 3.24$

Where, $E_{p d}$ is Class A pan evaporations in $\mathrm{mm} \mathrm{d}^{-1}$ derived from measured solar or shortwave radiation (Rs) in $M J m^{-2} d^{-1}$, daily maximum air temperature $\left(\mathrm{T}_{\max }\right)$ in ${ }^{\circ} \mathrm{C}$, and daily minimum relative air humidity $\left(\mathrm{RH}_{\min }\right)$ in \%.

\section{Class A pan coefficient and meteorological parameters}

Class A pan coefficient $\left(\mathrm{K}_{\mathrm{p}}\right)$ is the ratio of $\mathrm{ET}_{\mathrm{o}}$ and $\mathrm{E}_{\mathrm{p}}$. Its correlation with meteorological variables such as solar radiations $\left(R_{s}\right.$ and $\left.R_{n}\right)$, vapor pressure deficit (VPD), wind speed at $2 m\left(u_{2}\right)$, relative air humidity $(\mathrm{RH})$ and air temperature $(\mathrm{T})$ was too low $\left(\mathrm{R}^{2}<0.1\right)$. Also, the correlation between $\mathrm{K}_{\mathrm{p}}$ and $\mathrm{ET}_{\mathrm{o}}$ was too low $\left(R^{2}=0.1\right.$; RMSE $\left.=0.26\right)$. However, its correlation with $E_{p}$ for $E_{p} \geq 1$ $\mathrm{mm} \mathrm{d}^{-1}$ was relatively 'good' $\left(\mathrm{R}^{2}=0.50\right.$; RMSE $=0.19 ; \mathrm{n}=1483$; see Figure 12).

On the basis of the result of the linear regression model, for Tharandt site and places with similar climatic and or topographic characteristic with Tharandt, a rough estimate of summer halfyear daily values of Kp can be estimated from measured Ep (for 1 $\leq \mathrm{Ep} \leq 7.2 \mathrm{~mm} \mathrm{~d}-1$ ); range $=[0.388,1.38]$ (see Eq. 16). 
$K_{p}=1.54-0.16 E_{p}$

$K_{p}$ can also be estimated from derived $E_{p}\left(E_{p d}\right)\left(\right.$ for $\left.-0.5 \leq E_{p d} \leq 7.2 \mathrm{~mm} \mathrm{~d}^{-1}\right)$; range $=[0,1.54]$

as $K_{p}=1.44-0.2 E_{p d} \approx 1.44-0.2\left(0.4 R_{s}+0.13 T_{\max }-0.03 R H_{\min }+1.5\right) / 3.24($ see Eq. 17 and Eq. 18)

$K_{p}=1.44-0.2 E_{p d}$

$K_{p}=1.44-0.2\left(0.372 R_{s}+0.1312 T_{\max }-0.028 R H_{\min }+1.4866\right) / 3.24$

Where $\mathrm{K}_{\mathrm{p}}$ is Class A pan coefficient and $\mathrm{E}_{\mathrm{pd}}$ is derived Class $\mathrm{A}$ pan evaporation in $\mathrm{mm} \mathrm{d}^{-1}$.

\section{Conclusion}

At Tharandt for the summer half-year from 2004 to 2013 evaporation was mainly driven by solar radiation and vapor pressure deficit. The correlation between air temperature and relative air humidity with evaporation schemes was also good. Sunshine duration, which is not considered in this study, might also have good correlation with evaporation schemes. The effect of wind in deriving evaporation was negligibly too low. Moreover, the effect of wind speed at $2 \mathrm{~m}\left(\mathrm{u}_{2}\right)$ was not uniform. For $\mathrm{u}_{2} \leq 1 \mathrm{~m} \mathrm{~s}^{-1}$, the evaporation schemes namely Class A pan evaporation, reference evaporation and potential evaporation (PET) according to Haude, Wendling and Penman increased with increasing values of $\mathrm{u}_{2}$, whereas, for $\mathrm{u}_{2}>1 \mathrm{~m} \mathrm{~s}^{-1}$, they slightly decreased with increasing values of $u_{2}$. Note however that the cause for the negligibly too low effect of wind speed at $2 \mathrm{~m}$ on evaporation schemes might have resulted due to topography of the study site. Because Tharandt station is located at the bottom of a 'V-shaped' valley in which there is a high shelter effect that could have an impact at least on the wind and sunshine duration. The non-uniform effect of wind speed (for $\mathrm{u}_{2}>1 \mathrm{~m} \mathrm{~s}^{-1}$ and for $\mathrm{u}_{2} \leq 1 \mathrm{~m} \mathrm{~s}^{-1}$ ) on evaporation schemes is not clear. It might happen due to the influence of the nearby Weißeritz river.

The correlation between Class A pan coefficient and meteorological parameters such as solar radiation, vapor pressure deficit, wind speed at $2 \mathrm{~m}$, relative air humidity, air temperature and reference evapotranspiration was too low. However, its correlation with Class A pan evaporatin $\left(E_{p}\right)$ was comparatively good. Thus, for Tharandt site and places with similar climatic and topographic characteristics with Tharandt, Class A pan coefficient can be estimated from $\mathrm{E}_{\mathrm{p}}$ alone with good accuracy. Also, at Tharandt, for the summer half-year $E_{p}$ can be estimated from reference evapotranspiration, net solar radiation, Class A pan coefficient, vapor pressure deficit, solar or shorwave radiation, maximum air temperature, minimum relative air humidity, relative air humidity, and air temperature with very good accuracy. Particularly, the estimation of Class A pan evaporation merely based on measured solar radiation, maximum air temperature and minimum relative humidity makes this study special. Inclusion of actual sunshine duration hours which might improve the accuracy of the estimation of Class A pan evaporation is recommended.

The results of this study can be used for other parts of the world; however, only after proper validation because for instance unlike the case in Tharandt, in other parts of the world, the contribution of wind speed in deriving evaporation (evapotranspiration) maybe even higher than vapor pressure deficit. Note also that the equations developed in this study are based on ten years of climate data of a single station. Therefore, the results of this article shall be evaluated again using at least thirty years of climate data from multiple stations, if available, as ten years may not be enough to draw a generalized and strong conclusion. Last but not least, the knowledge obtained from this study may be used for evaporation related study in Tharandt and in areas with similar climatic conditions with Tharandt which can serve for decision makers to take appropriate measures in various agriculture, water and forestry sectors. Because summer half-year evaporation and precipitation amounts were almost equal, this study can also be implemented in warmer areas of the world with some modifications.

\section{Acknowledgment}

First of all, I do praise GOD and GOD's Mother above all. I

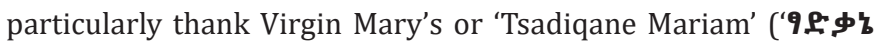

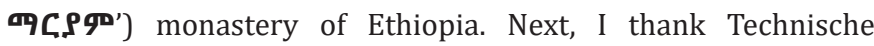
Universität Dresden, Faculty of Environmental Sciences, Institute of Hydrology and Meteorology, Chair of Meteorology for providing me all the data used for the study. I also thank DAAD, the National Meteorology Agency of Ethiopia (NMA), and the Ethiopian Meteorology Society for giving me financial support during my master's study. Very special thanks to my official supervisors Prof. Dr. Christian Bernhofer and Dr. Uta Moderow for their excellent supervision during my master thesis (finished in 2017). I am also grateful to my friend Mr. Abebe Guadie and my lecturer Mr. Endalkachew Bekele; they supported me in the publication of my previous research article. Last but not least, I would like to thank my wife and my family and friends for their crucial support and for sharing love and happiness.

\section{Data Availability Statement}

All data used during the study were provided by a third party. Direct requests for these materials may be made to the provider as indicated in the Acknowledgements. Also, all models or code generated or used during the study are available from the corresponding author by request.

\section{ORCID}

Antensay Mekoya https://orcid.org/0000-0002-2895-4581

\section{References}

1. Isikwue BC, Audu MO Isikwue OM (2014) Evaluation of Evapotranspiration using FAO Penman-Monteith Method in Kano Nigeria. International Journal of Science and Technology 3(11): 698703.

2. Moderow U, Aubinet M, Feigenwinter C, Kolle O, Lindroth A, et al. (2009) Available energy and energy balance closure at four coniferous forest sites across Europe. Theor Appl Climatol 98(3-4): 397-412. 
3. Wang K, Dickinson RE (2012) A review of global terrestrial evapotranspiration: Observation, modeling, climatology, and climatic variability. Rev Geophys 50(2).

4. Qin M, Hao L, Sun L, Liu Y, Sun G (2017) Climatic controls on watershed reference evapotranspiration vary dramatically during the past 50 years in southern China. Hydrol Earth Syst Sci.

5. Ertek A (2011) Importance of pan evaporation for irrigation scheduling and proper use of crop-pan coefficient $\left(\mathrm{K}_{\mathrm{cp}}\right)$, crop coefficient $\left(\mathrm{K}_{\mathrm{c}}\right)$ and pan coefficient $\left(\mathrm{K}_{\mathrm{p}}\right)$. African Journal of Agricultural Research $6(32)$ : 6706-6718

6. Antensay M, Christian B, Moderow U (2019) Estimation of Evaporation using Daily and Ten-Minute Class-A Pan Data from Automatic Measuring Pressure Sensor Instrument at Tharandt, Germany. Int J Environ Sci Nat Res 19(1): 556003.

7. Weiß M, Menzel L (2008) A global comparison of four potential evapotranspiration equations and their relevance to streamflow modeling in semi-arid environments. Adv Geosci 18: 15-23.

This work is licensed under Creative Commons Attibution 4.0 License

DOI:10.19080/IJESNR.2020.24.556134
8. Wendling U (1991) Schätzmethoden der Verdunstung landwirtschaftlicher Bestände nach den Ansätzen von Penman und Turc. = 'Estimating evaporation in crop stands according to Penman and Turc formulas.' (in German, with English summary). Arch. AckerPflanzenbau Bodenkd 35: 251-257.

9. ASCE-EWRI (2002) The ASCE Standardized Reference Evapotranspiration Equation Appendices A-F. Environmental and Water Resources Institute (EWRI) of the American Society of Civil Engineers (ASCE) Standardized Reference Evapotranspiration Task Committee (TC).

10. Allen RG, Pereira LS, Raes D, Smith M (1998) Crop evapotranspiration: Guidelines for computing crop water requirements. FAO Irrig and Drain, Paper No. 56, Food and Agricultural Organization of the United Nations, Rome, Italy.

Your next submission with Juniper Publishers will reach you the below assets

- Quality Editorial service

- Swift Peer Review

- Reprints availability

- E-prints Service

- Manuscript Podcast for convenient understanding

- Global attainment for your research

- Manuscript accessibility in different formats (Pdf, E-pub, Full Text, Audio)

- Unceasing customer service

Track the below URL for one-step submission https://juniperpublishers.com/online-submission.php 